\title{
Erratum to: From Tokyo to Khabarovsk: Soviet War Crimes Trials in Asia as Cold War Battlefields
}

\section{Valentyna Polunina}

\section{Erratum to:}

K. von Lingen (ed.), War Crimes Trials in the Wake of Decolonization and Cold War in Asia, 1945-1956, https://doi.org/10.1007/978-3-319-42987-8_11

The original version of the book was inadvertently published without incorporating the illustrations 1,2 , and 3 . The images have been included in this erratum instead.

The updated online version of this chapter can be found at https://doi.org/10.1007/978-3-319-42987-8_11 
E2 ERRATUM TO: FROM TOKYO TO KHABAROVSK: SOVIET WAR CRIMES TRIALS...

1. General Yamada depicted as a 'fascist plague flea,' Izvestiya, 13 December 1949

2. 'The mysterious disappearance of General Ishii, Izvestiya, 16 January 1950
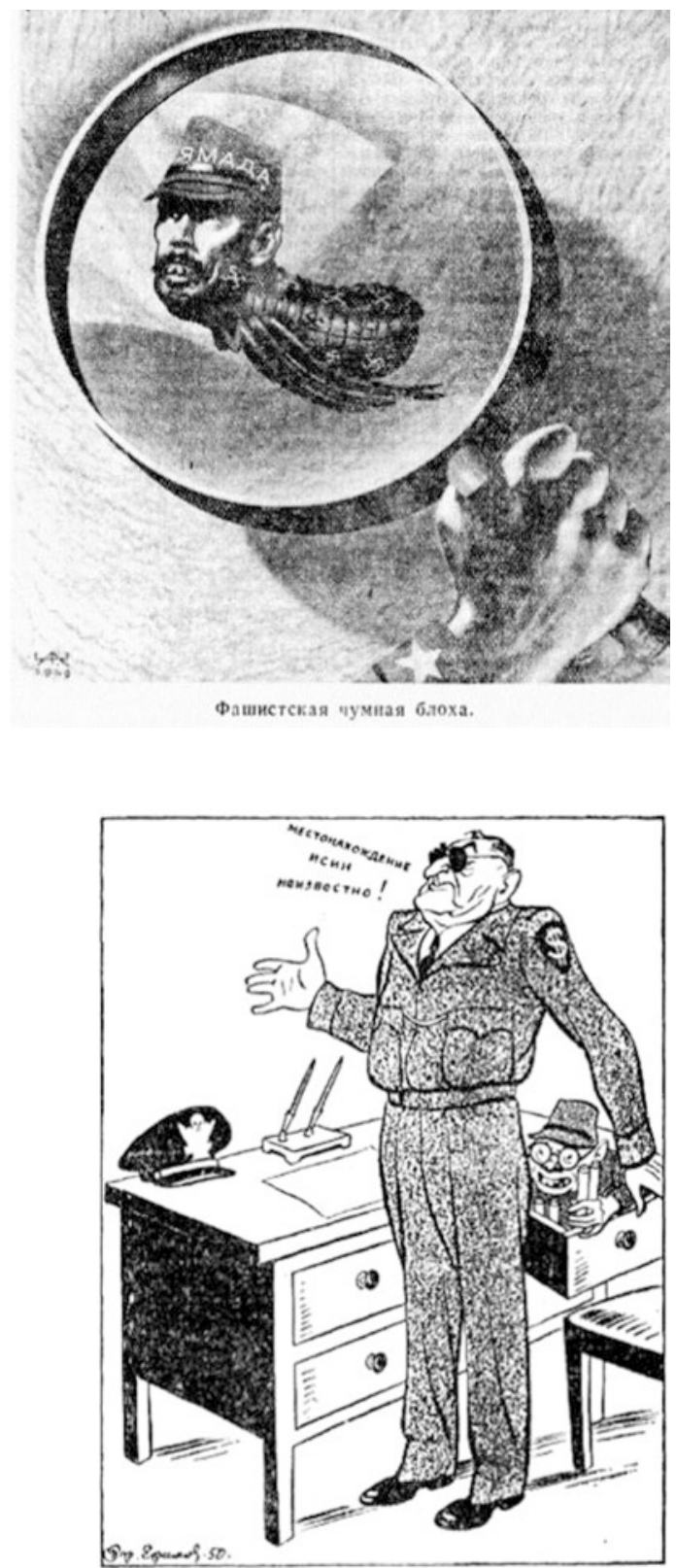
3. 'Unfulfilled dreams of Samurai,' Ogoniok, 8 January 1950

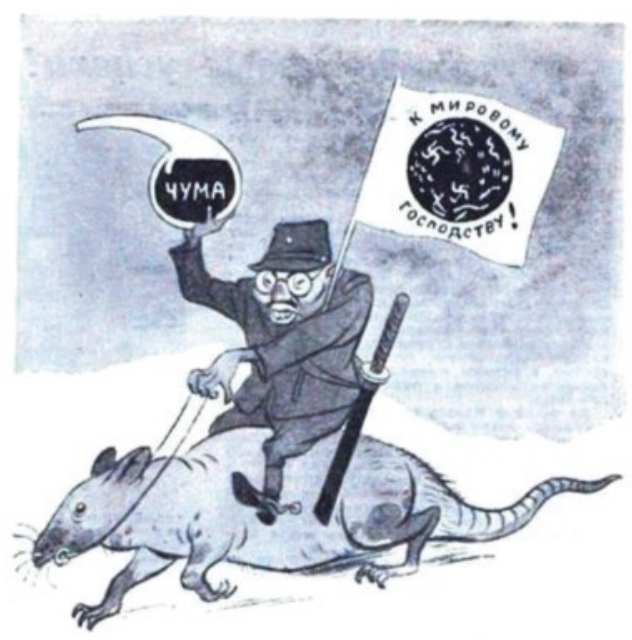

HЕОСУЩЕСТВЛЕНHЫЕ MEЧTЫ САMУРАЕВ.

Pucymon Eop. Eфumoea 